\title{
PUBLIC HEALTH POLICY AND PRACTICE
}

\section{Society for Social Medicine 1977-1992}

K McPherson, K Dunnell

J Epidemiol Community Health 2002;56:347-348

This paper continues the history of the Society for Social Medicine. The early history of the society is described in an accompanying paper by John Pemberton, which is published in this issue of the journal.

B 1972 the society had 275 members doubling in size over the next 10 years. By 1992 it had 1000 members and has continued to grow.

\section{ANNUAL SCIENTIFIC MEETINGS}

As Ian Leck has noted in his paper about the society 1956 to 1996, the principal activity has been its annual scientific meeting. ${ }^{1}$ Attendance at meetings has not grown in the same way as membership. For example, 260 attended in 1977 and around 300 during the late 1980s and early 1990s. There have been exceptions when, for example, 440 people attended the meeting in Oxford in 1984.

The nature of the meeting has changed dramatically however. In the early years all papers were presented in plenary sessions. As the number of papers, submitted and rejected, rose the issue of having parallel sessions was raised. This was rejected at first but was eventually introduced in the 1980s. This permits 70 papers to be presented in four parallel sessions. As again Leck has noted the dominant subject matter has also changed from epidemiology to an emphasis on health services research.

Another innovation was the introduction of a lecture in appreciation of Archie Cochrane who died in 1989. He left the society a small sum of money, which is used to pay a small fee and expenses to the chosen lecturer.

\section{ANGLO-FRENCH MEETINGS}

The first Anglo-French meeting was held in Rennes in 1972. They continued to be held in most years up until the 13th in 1988. Interest and support had dwindled somewhat by then as interest in creating wider European links grew. The meetings were often focused on particular topics, were bilingual, and attracted about 40-50 people.

Correspondence to: Professor K McPherson, MRC Health Services Research Collaboration Department of Social Medicine, Bristol

University, Canynge Hall,

Whiteladies Road, Bristol

BS8 2PR, UK;

Klim.McPherson@

bristol.ac.uk controversies and scientific evidence, and in 1990 by one on research policy.

During the 1980s there was a systematic attempt to arrange two meetings a year in addition to the annual scientific meeting. This goal was not always achieved but a range of meetings was held and were very successful educational/scientific events. Some topics covered over the years have been: Theory in social medicine, Smoking, Prevention of nuclear war, Government health statistics, Industry and community health, Pathways from early environment to adult disease, Health inequalities, Health and housing. Such meetings have allowed the society and its members to explore in detail scientific issues of the day that cannot be considered in depth at the annual meeting.

\section{HEALTH STATISTICS USER GROUP}

Throughout the history of the society there has always been interest in official health statistics as they form the basis of so much research. In 1980 a meeting was held in collaboration with the Statistics User Council to explore the topic in depth. Finally, in 1992, a formal Health Statistics User Group affiliated to the Statistics User Council was set up. This continues to play an important part in influencing the direction of official health statistics.

\section{OTHER ACTIVITIES}

The society has also been active in organising forums about undergraduate and graduate teaching. These have provided support to members teaching multidisciplinary courses and played an important part in developing curriculums for public health teaching.

Another theme that has frequently been a concern of the society is that of data confidentiality. The society coordinated views on how to balance patient confidentiality with the need to use records for research. During the 1980s this focused on the creation of the Data Protection Authority and in the 1990s on the draft of the EC Directive on data protection. The issue is still a live one because of the Human Rights Act and Health Service legislation.

\section{OTHER SOCIETIES}

Members of the society have always been interested in collaborating with comparable societies in other countries. The interest in the AngloFrench connection developed during the 1990s into providing major support for the creation of EUPHA and the launching of its journal. This support continues.

The IEA is also a society with greatly overlapping interests. Various joint meetings have been arranged over the years. 
The role of the Society for Social Medicine since the 19960s has been crucial in the development of academic public health. The Society has offered the only truly multidisciplinary, and largely scientific, forum for discussion and presentation of research findings at its annual scientific meetings. With now more than 1000 members from all disciplines, but deficient in economists and recently public health physicians, the main activity is between relatively junior public health researchers often presenting their research for the first time in a full programme of diverse results. The discussion is often animated and there are research papers of a very varied quality. Most of the participants at the annual scientific meeting are from academic departments of public health, many of whom, of course, are the people who have, since 1974, been engaged in the multidisciplinary training of trainees in public health medicine.

\section{FACULTY OF PUBLIC HEALTH MEDICINE}

However, the society traditionally finds questions of actual public health policy, and particularly of professional and educational policy, very difficult to deal with; finding these matters essentially alien to its main purpose. This reflects its constitution but also must in part reflect the ambiguous attitude of the Society to the formation of the Faculty of Public Health Medicine in 1972. The established provision of training, support and career opportunities for public health medicine contrasts starkly with that for others in public health. These discrepancies, absolutely obvious to all during the years since its formation, have only now begun to be remedied. The consequent tensions, while mostly not expressed, might have only been exacerbated by such discussion in the society, because its multidisciplinary public health mode of working was exemplary, premised essentially on scientific and evidence based discourse. Clearly there have been some discussions around the roles of the social sciences and qualitative methods and "hard" epidemiology, giving rise to better understanding. The relative power of particular professions in public health has been well disguised, on the whole.

However, much earlier, in the discussions that led to the original creation of the faculty, a working party of the society (consisting of 10 public health doctors) had in the autumn of 1969 made a "proposal" to guide its formation. This had proposed specifically (1) a new organisation with (2) the objectives of promoting high standards of training and practice. Its membership would (3) be restricted to registered medical practitioners but that later, with the agreement of Royal Colleges, consideration would be given to others engaged in academic community medicine.
Some opposition to these proposals was voiced at an extraordinary general meeting of the society in June 1970. Apparently 56 people attended of whom only six were not medically qualified. The opposition came from Margot Jefferys who thought that the exclusion of social scientists would be divisive and would reflect adversely on their status in their academic departments. She also felt that the association with the Royal Colleges would inevitably shift the emphasis of social medicine away from population studies towards social epidemiology. She was concerned too that the creation of the faculty would change the function of the society. It clearly did.

Margot Jefferys and Ann Cartwright conducted a ballot of members of the society. Of the 214 listed members some $67 \%$ favoured the formation of a faculty and $75 \%$ favoured the inclusion of non-medically qualified members. Only $44 \%$ of the members were in favour of people who were not medically qualified being excluded by such a move; $47 \%$ of the medically qualified members. Thus the society was then clearly pressing for a faculty that concerned itself with education and training for public health, and the maintenance of high standards, but that was multidisciplinary.

However, the lure of a fellowship of the Royal College of Physicians, by tying the faculty to the RCP, was too much for many of the medical officers of health, who generally felt undervalued by their clinical colleagues, and cared little for the academic niceties of multidisciplinary social medicine. Of course such a prize was not to be anyway, as the College of Physicians pretty smartly rejected any such proposal. The faculty had to award its own fellowships that are, only in 2001, being opened to honorary members of the faculty who are not medically qualified practitioners of public health.

Clearly the integration of public health policy with public health practice by an integrated public health workforce, which is fit for purpose, based on a research evidence based agenda is still a long way off. But the need becomes clearer as the evidence base advances and as the role of the society strengthens.

\section{Authors' affiliations}

K McPherson, MRC Health Services Research Collaboration, Department of Social Medicine, Bristol University, Bristol, UK

K Dunnell, Office of National Statistics, London, UK

\section{REFERENCE}

1 Leck I. The Society for Social Medicine; 1956-1996. J Epidemiol Community Health 1996;50:177. 